\title{
A link between the Hippocampal and the Striatal Memory Systems of the Brain
}

\author{
JANINE I. ROSSATO ${ }^{1}$, CAROLINA G. ZINN ${ }^{1}$, CRISTIANE FURINI ${ }^{1}$, LIA R.M. BEVILAQUA ${ }^{2}$ \\ JORGE H. MEDINA ${ }^{3}$, MARTÍN CAMMAROTA ${ }^{1}$ and IVÁN IZQUIERDO ${ }^{1}$ \\ ${ }^{1}$ Centro de Memória, Instituto de Pesquisas Biomédicas \\ Pontifícia Universidade Católica do Rio Grande do Sul (PUCRS), Av. Ipiranga 6690 \\ 90610-000 Porto Alegre, RS, Brasil \\ ${ }^{2}$ Departamento de Bioquímica, Universidade Federal do Rio Grande do Sul \\ Rua Ramiro Barcelos 2600 - Anexo, 90035-003 Porto Alegre, RS, Brasil \\ ${ }^{3}$ Instituto de Biologia Celular y Neurociencias "Prof. Dr. Eduardo de Robertis”, Paraguay 2155 \\ Facultad de Medicina, Universidad de Buenos Aires, Buenos Aires, CP 1121, Argentina
}

Manuscript received on November 16, 2005; accepted for publication on February 3, 2006; contributed by IVÁN IZQUIERDO*

\begin{abstract}
Two major memory systems have been recognized over the years (Squire 1987): the declarative memory system, which is under the control of the hippocampus and related temporal lobe structures, and the procedural or habit memory system, which is under the control of the striatum and its connections. Most if not all learning tasks studied in animals, however, involve either the performance or the suppression of movement; this, if learned well, may be viewed as having become a habit. It is agreed that memory rules change from their first association to those that take place when the task is mastered. Does this change of rules involve a switch from one memory system to another? Here we will comment on: 1) reversal learning in the Morris water maze (MWM), in which the declarative or spatial component of a task is changed but the procedural component (to swim to safety) persists and needs to be re-linked with a different set of spatial cues; and 2) a series of observations on an inhibitory avoidance task that indicate that the brain systems involved change with further learning.
\end{abstract}

Key words: hippocampus, striatum, declarative memory, procedural memory, habits, learning.

\section{INTRODUCTION}

Explicitly or implicitly, learning tasks in animals involve the performance or the inhibition of some form of movement in response to sensory or other cues. Clearly, when they become well learned by repetition, memories of these tasks may be viewed as habits. Of the various training procedures used, perhaps the most popular in the past few years are the

*Member Academia Brasileira de Ciências

Correspondence to: Iván Izquierdo

E-mail: izquier@terra.com.br
Morris water maze (MWM), one-trial inhibitory (or passive) avoidance, and various forms of fear conditioning, all of which closely mimic human situations of daily life. In the three forms of learning there is both a declarative component and the formation of a habit. In the cued version of the Morris maze, rodents learn to swim the shortest possible distance between the borders of a water tank to a hidden platform hidden slightly below the surface. They learn this guided by pictures in the wall or other visual cues external to the apparatus. This spatial version 
of the task is dependent on the hippocampus (Morris et al. 1986, 2003); its hippocampal biochemical mechanisms have been partly identified (Riedel et al. 2003, Fonseca et al. 2004, Teather et al. 2005) and they differ little from those of other hippocampal tasks (Izquierdo and Medina 1997). There is a non-spatial version of the MWM in which no external spatial cues are presented, the animals can actually see the platform because it is slightly above the water level, and the animals learn their way to the platform through exploration of the tank; this purely procedural version depends on the striatum (Packard and McGaugh 1992, Teather et al. 2005). Both water maze tasks can be modulated by the basolateral amygdala (Packard et al. 1994). It must be borne in mind that even in the spatial version of this task there is a procedural learning embedded: i.e., to swim in order to escape, which is very rapidly acquired as a habit (Morris et al. 1986, 2003). The learning of where to escape to (the one oriented by the spatial cues) is declarative information that hinges on or is superposed upon the swimming-toescape knowledge.

In the inhibitory avoidance task animals learn not to step down from a platform or step through a door in order to avoid entering a place where they once received a footshock. This task relies heavily on the dorsal hippocampus (Lorenzini et al. 1996, Izquierdo and Medina 1997), where it uses a sequence of molecular events very remindful of those of long-term potentiation (Bernabeu et al. 1997, Izquierdo and Medina 1995, 1997); but it also depends on the entorhinal and parietal cortex and is intensely modulated by the basolateral nucleus of the amygdala, in all of which it uses other sequences of molecular events (Izquierdo et al. 1992, Lorenzini et al. 1996, Izquierdo and Medina 1997, Bonini et al. 2003, Rossato et al. 2004). In the fear conditioning procedures, animals learn to put their skeletal muscles tense and avoid movement (i.e., to freeze) either in response to being placed in a certain compartment (contextual fear) or when an acoustic or other stimulus is given while they are in that compartment ("conditioned fear"). Needless to say, this nomenclature is incorrect, inasmuch as both contextual and cued fears are conditioned: in the former the CS is the context and in the latter it is a specific sensory stimulus.

Contextual fear is thought to rely heavily on the basolateral amygdala (Schafé et al. 1999, Nader 2003) and so-called "conditioned" fear depends on the hippocampus (e.g., Gilmartin and McEchron 2005). Evidence, however, also suggests a mostly modulatory role of the amygdala in the former, a role of the amygdala in the encoding of sensoryconditioned fear (Maren et al. 2001, Knight et al. 2005), and a role of the CA1 region of the hippocampus ( $\mathrm{Li}$ et al. 2005) and/or of CA3 (Daumas et al. 2005) in contextual fear formation. The question of whether the hippocampus and the amygdala play a role in the storage of one versus another form of fear motivated learning (contextual as opposed to conditioned) thus remains open (see Le Doux 2000, Maren et al. 2001, Goosens and Maren 2003). Calandreau et al. (2005) have shown that the basolateral amygdala is selectively involved in contextual learning, whereas the lateral amygdala is predominantly but not exclusively involved in "elemental" learning using a tone as CS. This dichotomy of function within the amygdala might explain at least some of the major discrepancies. Other data point to a complementary role of the amygdala and hippocampus in appetitive (Holahan 2005) and in avoidance learning (Izquierdo et al. 1992).

A recent article by $\mathrm{McGaugh}(2005)$ revives and perhaps bridges this problem as it suggests a role for enhanced amygdala activity during emotional arousal within the old perseveration-consolidation hypothesis. This author produced solid evidence through the years for a general role of the basolateral amygdala in the modulation of emotionally-laden memories, rather than in their storage (see McGaugh 2004). Should the amygdala play a role in consolidation and storage in addition to that of the hippocampus, it would merit being viewed as the center of a third memory system, separate from those governed by the hippocampus and the striatum (Phelps 2004). The question is of more 
than just theoretical importance, inasmuch as separate systems could have each a pathology of its own and host separate memory syndromes. So far, amygdala lesions in humans have been shown to rather selectively impair encoding and retrieval of very aversive or emotion-laden memories (Adolphs et al. 1997). This is not by itself sufficient to postulate anything more than a modulatory role for this structure (McGaugh 2004). But this role could be crucial and more necessary for some learnings than for others, which might explain several of the discrepancies (McGaugh 2004, 2005).

So far, more emphasis has been placed on the dichotomies between the striatal and the hippocampal memory systems (e.g., Packard et al. 1994, Korol and Kolo 2002, Canal et al. 2005, Pych et al. 2005, Teather et al. 2005) than on their eventual complementary or cooperative role. Here we will review two cases of linkage between the striatal and the hippocampal memory systems: one revealed by reversal learning in the MWM, and another one revealed by learning twice in a step-down inhibitory avoidance paradigm. Direct anatomical connections between the hippocampus and the striatum (mainly the nucleus accumbens) have been well studied recently; they are abundant, complex, and very well systematized, suggesting various possibilities of interaction (Voorn et al. 2004). In addition, connections between striatum and hippocampus via the entorhinal and prefrontal cortex (Hyman et al. 1990, Christakou et al. 2004) have been also well studied.

\section{THE CASE OF REVERSAL LEARNING IN THE MORRIS WATER MAZE}

Rats were trained in a circular pool $(200 \mathrm{~cm}$ diameter) to find, by swimming, a black circular platform (15 $\mathrm{cm}$ in diameter) submerged $2 \mathrm{~cm}$ below the water surface. The swimming path of the rats was recorded using a video camera mounted above the center of the pool and analyzed using a video tracking and analysis system. The water maze was located in a well-lit white room with several posters and other distal visual stimuli hanging on the walls to provide spatial cues. Training in the hidden platform (spatial, declarative, hippocampal) version of the MWM was carried out during 5 consecutive days. On each day rats received 8 consecutive training trials at 30-s intervals during which the hidden platform was kept in a constant location. A different starting location was used on each trial, which consisted of a swim followed by a 30-s platform sit. Any rat that did not find the platform within $60 \mathrm{~s}$ was guided to it by the experimenter. When the purpose of the experiment was to analyze the effect of protein synthesis inhibition on the acquisition of the MWM memory, immediately after the eighth trial in each training day rats were dried and moved to the injection room where they received bilateral intra-CA1 infusions of anisomycin (ANI) or vehicle (saline) through indwelling cannulae. Memory retention was evaluated in a 60 -s probe trial carried out in the absence of the escape platform $24 \mathrm{~h}$ after the last training session. To evaluate the effect of ANI given after memory reactivation, rats were trained for 5 days as indicated above and 24 or $120 \mathrm{~h}$ after the last training trial were submitted to a probe test in the absence of the escape platform. Immediately after that they received intra-CA1 infusions of ANI or vehicle and memory retention was evaluated in a second probe test carried out either at 2, 24 or $120 \mathrm{~h}$ after the first one. On the 6th day, rats thus trained were submitted to a single session of reversal learning, consisting of eight 60-s trials in which the platform was placed in the opposite quadrant of the pool. Immediately after the eighth reversal trial the animals received intra-CA1 infusions of ANI or vehicle. Memory retention was evaluated in a probe test carried out either at 2, 24 or $120 \mathrm{~h}$ after the last reversal trial. In reversal learning animals must retain the procedural aspect of the task (to swim to a place of escape) and to forget or extinguish the original declarative aspect (to reach a certain quadrant using the spatial cues) and replace it by a new one. This reversal learning is fast, suggesting that it preserves part of the original mnemonic trace and accrues to it information about the novel position of the plat- 
form, thus representing a situation of lability during which reconsolidation would be expected to occur (Nader et al. 2000, Nader 2003, Frankland et al. 2004, Lee et al. 2004, Izquierdo and Cammarota 2004). To analyze whether reversal learning involves reconsolidation of the original memory, rats were trained in the MWM for 5 days ( 8 training sessions daily). On day 6 the escape platform was moved to the opposite quadrant of the pool and the animals were given 8 training sessions to find the platform in its new location. Immediately after that they received bilateral intra-CA1 infusions of vehicle or ANI (160 $\mu \mathrm{g} / \mathrm{side})$. Memory retention was evaluated in a probe test carried out at 2, 24 or $120 \mathrm{~h}$ after reversal learning. Rats that received intra-CA1 vehicle normally acquired the reverse spatial preference but those given ANI failed to do so $(\mathrm{t}(36)$ $=3.54 ; \mathrm{p}<0.01 \mathrm{vs}$. VEH at $+24 \mathrm{~h}$ and $\mathrm{t}(20)=2.49$; $\mathrm{p}<0.05$ vs. VEH at $+120 \mathrm{~h}$ ). Moreover, the animals that received ANI did not show preference for the initial quadrant either, suggesting that the original memory had also been lost. Interestingly the effect of ANI was not seen when the animals were tested $2 \mathrm{~h}$ post-training, indicating that the ANI-induced amnesia is not immediate and confirming that this protein synthesis inhibitor is indeed blocking a protracted process that controls the long-lasting stabilization of the mnemonic trace. Thus, in reversal learning in the MWM animals must retain a procedural (and so probably striatal) memory, unlink it from an original declarative (and so probably hippocampal) memory and link it instead to another declarative memory (the changed map). The entire process is quick, but along its duration the declarative component must be labilized (by definition), deleted and replaced by a new one. A reconsolidation process mediates the cutting and pasting of the two pieces of memory: the one that consists of just swimming-to-escape (procedural), which persists throughout, and the one that consists of swimming-to-a-specific-location (declarative), which was changed. This cutting and pasting may be viewed as a form of reconsolidation in the literal sense of the word. Like other forms of reconsolidation that have been described (Milekic and Alberini 2002, Debiec et al. 2002, Nader 2003), the reconsolidation intrinsic to reversal learning in the MWM depends on hippocampal protein synthesis, as do others that have been described (Milekic and Alberini 2002, Debiec et al. 2002). It differs from those other forms of reconsolidation conceptually (it involves cutting and pasting) and operationally (its result is a new memory).

\section{INHIBITORY AVOIDANCE LEARNING: LEARNING LITTLE AND LEARNING MORE}

Inhibitory avoidance learning is usually carried out in one session. The animals (rats or mice) are placed in a compartment or on a platform facing a grid. After a usually very brief exploration of the start compartment (i.e., $>10 \mathrm{sec}$ ), the animals enter the grid compartment; as soon as they place their four paws on the grid they receive a footshock. If placed again on the platform or on the safe side hours, days or months later (short-, long- and remote memory, respectively (Izquierdo et al. 1992), they will remain there for several seconds or minutes. The test session step-down latency depends on the intensity of the footshock. Using 0.4-0.5 mA, 2-sec footshock, test step-down latency is usually of about $40 \mathrm{sec}$; if the training footshock is higher $(0.8-1.0 \mathrm{~mA}$ the retention score is usually much higher ( 3 or more min) (Quevedo et al. 2005, Cammarota et al. 2004, 2005). Inhibition of their natural exploratory tendency to explore beyond the safe area constitutes a conditioned avoidance response; i.e., an instrumental conditioned reflex. The platform or the safe compartment may be viewed as a CS, the footshock is the US, and the inhibitory avoidance is the CR (Izquierdo et al. 1992).

This task is more complex than what it looks like: it has several components. One is knowledge about the apparatus, which can be enhanced by preexposure of the animals to it one day prior to training without the shock. This knowledge is part of the task and can prevent the posttraining amnesic influence of the N-methyl-D-aspartate (NMDA) glutamate receptor blocker, 2-amino-5-phosphono pen- 
tanoic acid (AP5) (Izquierdo et al. 1992) given after regular training on the next day. The other major component is, of course, the footshock; but only if specifically linked to the CS (Alonso et al. 2002). A footshock out of context serves no purpose in acquisition or consolidation; but it may serve as a reminder in a further test session, or may generate contextual fear if carried out repeatedly and unaccompanied by a specific CS in a different context (Schafé et al. 1999).

We studied the effect of a variety of treatments given bilaterally $15 \mathrm{~min}$ before or $3 \mathrm{~h}$ after the $1 \mathrm{st}$ ( $\operatorname{Tr} 1)$ or the 2 nd ( $\operatorname{Tr} 2)$ daily training session of stepdown avoidance training into the hippocampus and/ or the dorsal striatum of rats. Infusion volume was $0.5 \mu \mathrm{l} / \mathrm{side}$. Infusions lasted $30 \mathrm{sec}$ on each side, and the cannulae were kept in place for an additional $15 \mathrm{sec}$ (Izquierdo et al. 1992, Izquierdo and Medina 1997, Cammarota et al. 2004, 2005). Some of the treatments were given at the times mentioned before or after a single training session (Tr1) and these animals were tested just once (T1). Other animals received another 0.5 footshock after the $\mathrm{T} 1$ and thus this became not only a first test but a second training session $(\operatorname{Tr} 2)$. These animals were then tested again for a second time (T2). The interval between sessions ( $\mathrm{Tr}, \mathrm{T} 1 / \mathrm{Tr} 2$, and T2) was $24 \mathrm{~h}$.

The drugs studied were AP5 (D-2-amino-5phosphonepentanoate), DNQX (6,7-dinitroquinoxaline-dione), AP3 (2-amino-3-phosphone pentanoate), DRB (6-dichloro-1-beta-d-ribofuranosyl benzimidazole); anisomycin, KN93 (N-[2-(N-chlorocynnamyl) - N - methylaminomethyl) phenyl] - N [2-hydroxyethyl] - 4 - methoxybenzene - sulfonamide), H89 (N-[2-((p-bromocynammil)amino)ethyl]5-isoquinolinesulfonamide) or U0126 (1,4-diamino-2,3-dicyano-1,4-bis[2-aminophenylthio] butadiene). AP5, DNQX and AP3 are selective antagonists of glutamate NMDA (N-methyl-D-aspartate), AMPA ( $\alpha$-amino-3-hydroxy-5-methyl-4-isoxazole propionate) and metabotropic type I receptors, respectively. DRB is an inhibitor of RNA polymerase II that blocks gene expression. Anisomycin is an inhibitor of protein synthesis. KN93 inhibits Ca2+/ calmodulin dependent protein kinase II (CaMKII). U0126 inhibits ERK1/2 activation. H89 selectively inhibits the cAMP-dependent protein kinase (PKA). Two of the treatments (AP5 and anisomycin) were studied only by administration into the CA1 region of the hippocampus. The effect of DNQX, AP3, various protein kinase A, ERK and CaMKII inhibitors given in the hippocampus is amply documented in several recent papers from our group (see Izquierdo and Medina 1997, Bonini et al. 2003, Rossato et al. 2004, Cammarota et al. 2005). In particular, the entire list of drugs mentioned above, using other PKA inhibitors instead of H89, at the same doses and at these same times of injection are well known to cause strong amnesia for the present task when given into CA1 (Izquierdo et al. 1992, Bernabeu et al. 1997, Izquierdo and Medina 1997). All the treatments listed above were studied in the striatum by their administration 15 min before training sessions. Some which we knew from previous papers that also have effects on consolidation when given into other brain areas $3 \mathrm{~h}$ after training (see references above) were also studied by their infusion $3 \mathrm{~h}$ after training (see below). AP5 and anisomycin drugs were amnesic for the memory of one-trial avoidance (Tr1-T1; AP5 only at the -15 min infusion time) regardless of whether the task was acquired to a low $(0.5 \mathrm{~mA}$ footshock) or to a high criterion ( $0.8 \mathrm{~mA}$ footshock). For the effect of the other drugs on one-trial avoidance, see Izquierdo and Medina 1997, Izquierdo et al. 2002).

Memory consolidation of this task acquired in one trial requires a large array of molecular events in the hippocampus (Izquierdo and Medina 1997, Alonso et al. 2002, Quevedo et al. 2005, Cammarota et al. 2005), which include the early activation of NMDA receptors, the early $(0 \mathrm{~h})$ and late $(3 \mathrm{~h})$ activation of protein kinase $\mathrm{A}$, and the late (2-3 h) activation of the ERK1/2 (Izquierdo et al. 1992, Izquierdo and Medina 1997, Bernabeu et al. 1997, Taubenfeld et al. 1999, Cammarota et al. 2000, 2005, Quevedo et al. 2005). In contrast, none of the treatments, except AP3, has any effect on $\mathrm{T} 1$ when given before or after $\operatorname{Tr} 1$ in the stria- 
tum. Thus, in terms of one-trial inhibitory avoidance learning ( $\operatorname{Tr} 1-\mathrm{T} 1)$, learning little $(0.5 \mathrm{~mA}$ footshock) or learning more ( $0.8 \mathrm{~mA}$ footshock) depends mainly on the hippocampus, but marginally on the striatum; although the striatum does register $\operatorname{Tr} 1$ through glutamate type I metabotropic receptors. In addition, a number of other receptors for modulatory neurotransmitters (dopamine, serotonin, and acetylcholine) in the striatum play a role in $\operatorname{Tr} 1$ when this involves, like here, a mild footshock; but not when it involves a strong footshock (Prado-Alcalá et al. 2003a, b). The modulatory nature of these effects is strongly suggested by the fact intra-striatal AP5 and anisomycin, which selectively block crucial steps of memory consolidation in many systems (Izquierdo and Medina 1997) do not affect the consolidation of $\operatorname{Tr} 1$, regardless of whether it is obtained using a mild or a strong footshock.

\section{INHIBITORY AVOIDANCE LEARNING: LEARNING TWICE}

Our findings indicate that the striatum, unlike the hippocampus, amygdala or entorhinal cortex (Cammarota et al. 2004), plays a key role in the second round of consolidation brought about by $\operatorname{Tr} 2$, by which retention score rise from $30-50 \mathrm{sec}$ in $\mathrm{T} 1$ to $100 \mathrm{sec}$ or more in $\mathrm{T} 2$. This rise is blocked by all the drugs tested given $15 \mathrm{~min}$ before or $3 \mathrm{~h}$ after $\operatorname{Tr} 2$, except AP3. For this role in the consolidation of $\operatorname{Tr} 2$, the striatum requires the same molecular systems that are required by the hippocampus in order to consolidate Tr1: NMDA and AMPA (but not metabotropic) glutamate receptors, CaMKII, PKA, and ERK1/2. Thus, for inhibitory avoidance in the rat, learning twice is different from learning little and learning more in one session.

Is the striatum involved just in learning to a higher criterion or is it the site of a second round of consolidation triggered by Tr2? Prado-Alcalá and his coworkers have indicated that one-trial avoidance learned with a $0.8-1.0 \mathrm{~mA}$ footshock is not sensitive to a large variety of manipulations in the striatum which affect the consolidation of tasks learned with a lower footshock. In accordance with this, here we found that AP5 or anisomycin given into the striatum 15 min before a $\operatorname{Tr} 1$ with $0.8 \mathrm{~mA}$ have no effect on memory, which is in contrast to the strong amnesic effect that these drugs have when given into CA1. Training with a $0.8 \mathrm{~mA}$ footshock takes retention scores to levels similar to those obtained with two $0.5 \mathrm{~mA}$ sessions. Therefore, the striatum controls consolidation of learning twice, but not that of simply learning more in just one session. And it does so through mechanisms involving glutamatergic NMDA and AMPA receptors, CaMKII, PKA, ERK, gene expression and protein synthesis, like many other forms of memory (Izquierdo and Medina 1997). As happens in the hippocampus with $\operatorname{Tr} 1$ (Bevilaqua et al. 2005), the role of CaMKII appears more important for consolidation in the striatum at the time of $\operatorname{Tr} 2$ than $3 \mathrm{~h}$ later, whereas the role of PKA or the ERK1/2 pathway is manifested both at the time of training and $3 \mathrm{~h}$ later.

\section{FINAL COMMENTS}

The present article reviews two instances of very well known learning commonly studied in many laboratories all over the world and highly representative of a large spectrum of human learnings which were shown to use both the hippocampal and the striatal memory systems. In reversal learning in the MWM the animals must re-link the procedural (presumably striatal) component of the task with a new declarative set of stimuli (spatial and therefore presumably hippocampal). In inhibitory avoidance, exposing the animals to a second training session moves the consolidation process away from the hippocampus and into the striatum, at the time when the conditioned response may be viewed as having become a habit. Therefore, our findings endorse the view that the borders between memory systems are not so clear that tasks or forms of learning may be defined as just "declarative" or "procedural", or as just "hippocampal" or "striatal". Two very different and widely used learning tasks can be all of those things; if not at the same time, at least sequentially. 
So, in human pathology, one might expect dualities concerning the disruptions of memory that may result from lesion of either the medial temporal and the caudate-putamen or both. This might explain why in Parkinson's disease there may occur an amnestic syndrome that is remindful of temporal lobe amnesias, and why in, say, Alzheimer's disease there may be disruptions of forms of memory usually considered to be procedural.

\section{RESUMO}

Ao longo dos anos, têm-se identificado dois sistemas principais de memória (Squire 1992): o sistema das memórias declarativas, que está sob o controle do hipocampo e estruturas relacionadas do lobo temporal e o sistema das memórias procedimentais ou memórias para hábitos, que está sob controle do corpo estriado e suas conexões. Porém, quase todas as tarefas de aprendizado utilizadas para estudar a formação de memórias em animais envolvem a realização ou a supressão de movimentos e, se bem aprendidas poderia interpretar-se que essas memórias se converteram em um hábito. Sabe-se que os processos envolvidos na formação de memórias mudam na medida em que a associação original torna-se fortalecida através do treinamento. Será que esta mudança também envolve a passagem de um sistema de memória para outro? Aqui nós iremos comentar a respeito 1) do aprendizado reverso na tarefa do labirinto aquático de Morris (LAM), na qual o componente declarativo da tarefa muda, mas o componente procedimental (nadar para um lugar seguro) persiste e precisa ser re-associado a um grupo distinto de dicas espaciais e 2) a respeito de uma série de observações relacionadas com a tarefa de esquiva inibitória que indicam que os sistemas neurais envolvidos no processamento mnemônico mudam na medida em que o aprendizado original é reforçado.

Palavras-chave: hipocampo, corpo estriado, memória declarativa, memória procedimental, hábitos, aprendizado.

\section{REFERENCES}

Adolphs R, CAHILl L, SchUl R and Babinsky R. 1997. Impaired declarative memory for emotional material following bilateral amygdala damage in humans. Learn Mem 4: 291-300.

Alonso M, Viola H, IzQuierdo I and Medina JH. 2002. Aversive experiences are associated with a rapid and transient activation of ERKs in the rat hippocampus. Neurobiol Learn Mem 77: 119-124.

Bernabeu R, Bevilaqua L, Ardenghi P, BromBERG E, SCHMITZ P, BIANCHIN M, IZQUIERDO I AND MEDINA JH. 1997. Involvement of hippocampal D1/D5 receptor-cAMP signaling pathways in late memory consolidation.Proc Natl Acad Sci USA 94: 7041-7046.

Bevilaqua LR, Medina JH, Izquierdo I AND CAmmarota M. 2005. Memory consolidation induces $N$-methyl-D-aspartic acid-receptor- and $\mathrm{Ca}^{2+} /$ calmodulin-dependent protein kinase II-dependent modifications in $\alpha$-amino-3-hydroxy-5-methylisoxazole-4-propionic acid receptor properties. Neuroscience 136: 397-403.

Bonini JS, Rodrigues L, Kerr DS, Bevilaqua LR, Cammarota M and IzQuierdo I. 2003. AMPA/kainate and group-I metabotropic receptor antagonists infused into different brain areas impair memory formation of inhibitory avoidance in rats. Behav Pharmacol 14: 161-166.

Calandreau L, Desmedt A, Decorte L and JaFFARD R. 2005. A different recruitment of the lateral and basolateral amygdala promotes contextual or elemental conditioned association in Pavlovian fear conditioning. Learn Mem 12: 383-388.

Cammarota M, Bevilaua LR, Ardenghi P, PaRATCHA G, LEVI DE, STEN M, IZQUIERdo I AND MEDINA JH. 2000. Learning-associated activation of nuclear MAPK, CREB and Elk-1, along with Fos production, in the rat hippocampus after a one-trial avoidance learning: abolition by NMDA receptor blockade. Mol Brain Res 76: 36-46.

Cammarota M, Bevilaqua LR, Medina JH and IZQUIERDo I. 2004. Retrieval does not induce reconsolidation of inhibitory avoidance memory. Learn Mem 11: 572-578.

Cammarota M, Bevilaqua LR, Köhler C, MEdina JH AND IZQUiERdo I. 2005. Learning twice is different from learning once or from learning more. Neuroscience 132: 273-279.

Canal C, Stutz SJ and Gold PE. 2005. Glucose injections into the dorsal hippocampus or dorsolat- 
eral striatum of rats prior to T-maze training: modulation of learning rates and strategy selection. Learn Mem 12: 367-374.

Christakou A, Robbins TW AND Everitt B. 2004. Prefrontal cortical-ventral striatal interactions involved in affective modulation of attentional performance: implications for corticostriatal circuit function. J Neurosci 24: 773-780.

Daumas S, Halley H, Francés B And Lassalle J-M. 2005. Encoding, consolidation and retrieval of contextual memory: differential involvement of dorsal CA3 and CA1 hippocampal subregions. Learn Mem 12: 375-382.

Debiec J, LeDoux JE And Nader R. 2002. Cellular and systems reconsolidation in the hippocampus. Neuron 36: 527-538.

Fonseca R, NAGERL UV, MORRIS RG AMd BonHOEFFER T. 2004. Competing for memory: hippocampal LTP under regimes of reduced protein synthesis. Neuron 44: 1011-1120.

Frankland PW, Bontempi B, TALTON L, KACZMAREK L AND SILVA AJ. 2004. The involvement of the anterior cingulate cortex in remote contextual fear memory. Science 304: 881-883.

GILMARTIN MR AND MCECHRON MD. 2005. Single neurons in the dentate gyrus and CA1 of the hippocampus exhibit inverse patterns of encoding during trace fear conditioning. Behav Neurosci 119: 164-179.

Goosens KA And MARen S. 2003. Pretraining NMDA receptor blockade in the basolateral complex, but not the central nucleus, of the amygdala prevents savings of conditional fear. Behav Neurosci 117: 738-750.

HOLAHAN MR. 2005. Complementary roles for the amygdala and hippocampus during different phases of appetitive information processing. Neurobiol Learn Mem 84: 124-131.

Hyman BT, Van Hoesen GW and Damasio A. 1990. Memory-related neural systems in Alzheimer's disease: an anatomic study. Neurology 40: $1721-1730$

IZQUIERdo I AND CAMMAROTA M. 2004. Zif and the survival of memory. Science 304: 829-830.

IZQUIERDO I AND MEDINA JH. 1995. Correlation be- tween the pharmacology of long-term potentiation and the pharmacology of memory. Neurobiol Learn Mem 63: 19-32.

IZQUIERDO I AND MEDINA JH. 1997. Memory formation: the sequence of biochemical events in the hippocampus and its connection to activity in other brain structures. Neurobiol Learn Mem 68: 285-316.

IZQUIERdo I, DA CUNHA C, ROSAT R, JERUSALINSKY D, FERreira MBC AND MEdina JH. 1992. Neurotransmitter receptors involved in post-training memory processing by the amygdala, medial septum and hippocampus of the rat. Behav Neural Biol 58: 16-26.

IZQUIERdo LA, BARRoS DM, VIANNA MR, COITinho A, Dedavid e Silva T, Choi H, MoLeTtA M, MedinA JH AND IZQuierdo I. 2002. Molecular pharmacological dissection of short- and long-term memory. Cell Mol Neurobiol 22: 269 287.

Knight D, NguYen HT AND BAndettini PA. 2005. The role of the human amygdala in the production of conditioned fear responses. Neuroimage 26: 1193-1200.

Korol DL AND Kolo LL. 2002. Estrogen-induced changes in place and response learning in young adult female rats. Behav Neurosci 116: 411-420.

LEDOUX JE. 2000. Emotion circuits in the brain. Ann Rev Neurosci 23: 155-184.

LeE JL, Everitt BJ AND Thomas KL. 2004. Independent cellular processes for hippocampal memory consolidation and reconsolidation. Science 304 839-843.

Li Z, Li L, Mao R, Wang P, Peng W, Dong Z, XU L AND CAO J. 2005. Effects of unconditioned and conditioned aversive stimuli in an intense fear conditioning paradigm on synaptic plasticity in the hippocampal CA1 area in vivo. Hippocampus 15: 815-824.

Lorenzini CA, BALDi E, Bicherelli C, SACCHETTI B AND TAssoni G. 1996. Role of dorsal hippocampus in acquisition, consolidation and retrieval of rat's passive avoidance response: a tetrodotoxin functional inactivation study. Brain Res 730: 32-39.

Maren S, Yap SA And Goosens KA. 2001. The amygdala is essential for the development of neu- 
ronal plasticity in the medial geniculate nucleus during auditory fear conditioning in rats. J Neurosci 21 : RC135.

MCGAUGH JL. 2004. The amygdala modulates the consolidation of memories of emotionally arousing experiences. Ann Rev Neurosci 27: 1-28.

MCGAUGH JL. 2005. Emotional arousal and enhanced amygdala activity: new evidence for the old perseveration-consolidation hypothesis. Learn Mem 12: 77-79.

Milekic M AND Alberini CM. 2002. Temporally graded requirement for protein synthesis following memory reactivation. Neuron 38: 521-525.

MORRIS RG, ANDERSON E, LYNCH GS AND BAUDRY M. 1986. Selective impairment of learning and blockade of long-term potentiation by an N-methylD-aspartate receptor antagonist, AP5. Nature 319: 774-776.

Morris RG, Moser EI, Riedel G, Martin SJ, SANDIN J, DAY M AND OÇARROLl C. 2003. Elements of a neurobiological theory of the hippocampus: the role of activity-dependent synaptic plasticity in memory. Philos Trans R Soc B Biol Sci 358: 773786.

NADER K. 2003. Memory traces unbound. Trends Neurosci 26: $65-72$.

NADER K, Schafe GE AND LeDoux JE. 2000. Fear memories require protein synthesis in the amygdala for reconsolidation after retrieval. Nature 406: 722726.

PaCKard MG And McGaugh JL. 1992. Double dissociation of fornix and caudate nucleus lesions on acquisition of two water maze tasks: further evidence for multiple memory systems. Behav Neurosci 106 : 439-446.

Packard MG, Cahill L and McGaugh JL. 1994. Amygdala modulation of hippocampal-dependent and caudate nucleus-dependent memory processes. Proc Natl Acad Sci USA 91: 8477-8481.

PHELPS EA. 2004. Human emotion and memory: interactions of the amygdala and hippocampal complex. Curr Opin Neurobiol 14: 198-202.

Prado-Alcalá RA, Ruiloba Mi, Rubio L, Solana-Figueroa R, Medina C, Salado-CastilLO R AND QUIRARTE GL. 2003a. Regional infu- sions of serotonin into the striatum and memory consolidation. Synapse 47: 69-75.

Prado-Alcalá RA, Solana-Figueroa R, GalinDo LE, Medina AC AND Quirarte GL. 2003b. Blockade of striatal 5-HT2 receptors produces retrograde amnesia in rats. Life Sci 74: 481-488.

PyCh JC, Chang Q, COlón-Rivera C AND Gold PE. 2005. Acetylcholine release in hippocampus and striatum during testing on a rewarded spontaneous alternation task. Neurobiol Learn Mem 84: 93-101.

Quevedo J, Vianna MR, Roesler R, MARTins MR, De-PARIS F, MEdina JH AND IzQUiERdo I. 2005. Pretraining but not preexposure to the task apparatus prevents the memory impairment induced by blockade of protein synthesis, PKA or MAP kinase in rats. Neurochem Res 30: 61-70.

Riedel G, Platt B and Micheau J. 2003. Glutamate receptor function in learning and memory. Behav Brain Res 140: 1-47.

Rossato JL, BONini JS, COITINHO AS, Vianna MR, MEdinA JH, CAMMAROTA M AND IZQUiERDO I. 2004. Retrograde amnesia induced by drugs acting on different molecular systems. Behav Neurosci 118: 563-568.

Schafé GE, NAdel LV, Sullivan GM, HARris A AND LEDOUX JE. 1999. Memory consolidation for contextual and auditory fear conditioning is dependent on protein synthesis, PKA, and MAP kinase. Learn Mem 6: 97-110.

SQUIRE L. 1987. Memory and Brain. Oxford, University Press, Oxford New York USA.

Taubenfeld SM, WiIg KA, Bear MF And AlbeRINI CM. 1999. A molecular correlate of memory and amnesia in the hippocampus. Nature Neurosci 2: 309-310.

Teather LA, Packaed MG, Smith DE, EllisBEHNKE RG AND BAZAN N. 2005. Differential induction of c-Jun and Fos-like proteins in rat hippocampus and dorsal striatum after training in two water maze tasks. Neurobiol Learn Mem 84: 75-84.

Voorn P, VANDERSCHUREN LJ, GRoEnEWEGEN HJ, Robbins TW And Pennartz CM. 2004. Putting a spin on the dorsal-ventral divide of the striatum. Trends Neurosci 27: 468-474. 